\title{
Sexual selection and organs of sense: Darwin's neglected insight
}

\author{
Mark A. Elgar ${ }^{1, *}$, Tamara L. Johnson ${ }^{1}$ and Matthew R.E. Symonds ${ }^{2}$ \\ ${ }^{1}$ School of BioSciences, The University of Melbourne, Victoria 3010, Australia \\ ${ }^{2}$ Centre for Integrative Ecology, School of Life and Environmental Sciences, Deakin University, \\ Burwood, Victoria, Australia
}

Submitted: May 15, 2018. Final revision received: September 19, 2018. Accepted: October 12, 2018

\begin{abstract}
Studies of sexual selection that occurs prior to mating have focussed on either the role of armaments in intra-sexual selection, or extravagant signals for inter-sexual selection. However, Darwin suggested that sexual selection may also act on 'organs of sense', an idea that seems to have been largely overlooked. Here, we refine this idea in the context of the release of sex pheromones by female insects: females that lower the release of sex pheromones may benefit by mating with high-quality males, if their signalling investment results in sexual selection favouring males with larger or more sensitive antennae that are costly to develop and maintain.
\end{abstract}

\section{Keywords}

Antennae; chemical signal; mate choice; sex pheromone; sexual selection

\section{Introduction}

Antennae are a distinguishing feature of almost all adult insects, the majority of whom live in a sensory world dominated by odours. Insect antennae typically comprise three distinct structures that are broadly conserved across insects and allow almost omnidirectional movement of the antennae (Zacharuk, 1985; Elgar et al., in press). The distal structure, called the flagellum, has the greatest variation in length and shape both within and between species, and it supports numerous sensory hairs (sensilla) that bear receptors capable of perceiving odours (Schneider, 1964; Zacharuk, 1985). In addition to the remarkable diversity of shapes and sizes of insect antennae, there are also striking examples of sexual dimorphism (Schneider,

*) Corresponding author; e-mail: m.elgar@unimelb.edu.au 
1964). The most striking is the complete absence of antennae in adult females, but not males of the twisted-wing parasite Stylops melittae Kirby, 1802 (Strepsiptera; Stylopidae; Tolasch et al., 2012). More familiar examples of antennal sexual dimorphism are the large, feathery antennae of male moths that contrast with the simple filiform antennae of females (Allen et al., 2011; Symonds et al., 2012). Antennal sexual dimorphism is no less dramatic in other insects: the antennae of male longhorned beetles (Cerambycidae) can be very much longer than those of females. While male antennae are often larger or have a greater surface area than female antennae (Schneider, 1964), the nature and direction of sexual dimorphism in insect antennae varies, both between and within insect groups (table 1) - an absence of antennal sexual dimorphism is not uncommon, and selection can also favour larger antennae in females than males (table 1). Furthermore, sexual dimorphism in antennal morphology can include the diversity, density and size of sensilla supported by the antennae (table 1).

Remarkably, few studies have attempted to account for the evolution of both the diversity of antennal morphology (Elgar et al., in press), and more specifically the patterns of antennal sexual dimorphism. The conventional wisdom is that more elaborate and larger antennae accommodate the additional sensory requirements of males to detect sex pheromones that reveal the location of sexually receptive females (e.g., Schneider, 1964; Chapman, 1982; Elgar et al., in press). Additionally, modified antennae in some species may have other functions, such as helping to grasp the female (Mohamedsaid, 2004), repel rival males (Ray et al., 2009), or in retaining a reservoir of air for water beetles (Hydrophilidae) (Schneider, 1964). Detecting these sex pheromones requires specific receptors, and so large antennae may provide greater surface area for the additional sensilla necessary to support the increased numbers of receptors (e.g., Schneider, 1964; Elgar et al., in press).

Olfactory sensory systems differ from other modalities in a crucial manner: signal perception requires a physical interaction between the chemical molecules that comprise the odour and specific receptors that are located on the sensilla (Elgar et al., in press). It is widely assumed that the probability of odorant-receptor interactions is increased with larger antennal surface area that supports more sensilla. Yet this view has not been subject to extensive empirical investigations (Spaethe et al., 2007), and other features of the antennae, such as antennal scales (Wang et al., 2018a), may also be important for odour-receptor interactions.

The exquisite, elaborate antennae of male moths are typically thought to support more sensilla, necessary because sex pheromones are released in minute quantities and must be detected at great distances from the female (Symonds \& Elgar, 2008; Wyatt, 2014). This explanation lacks generality, however, because the vast majority of male moths do not have pectinate antennae (Mankin \& Mayer, 1984; Symonds et al., 2012). Nevertheless, the direction and degree of sexual dimorphism in antennal morphology is not consistent across insect clades (table 1; see also Schneider, 1964), suggesting a role for sexual, rather than natural selection. 
M.A. Elgar et al. / Animal Biology 69 (2019) 63-82

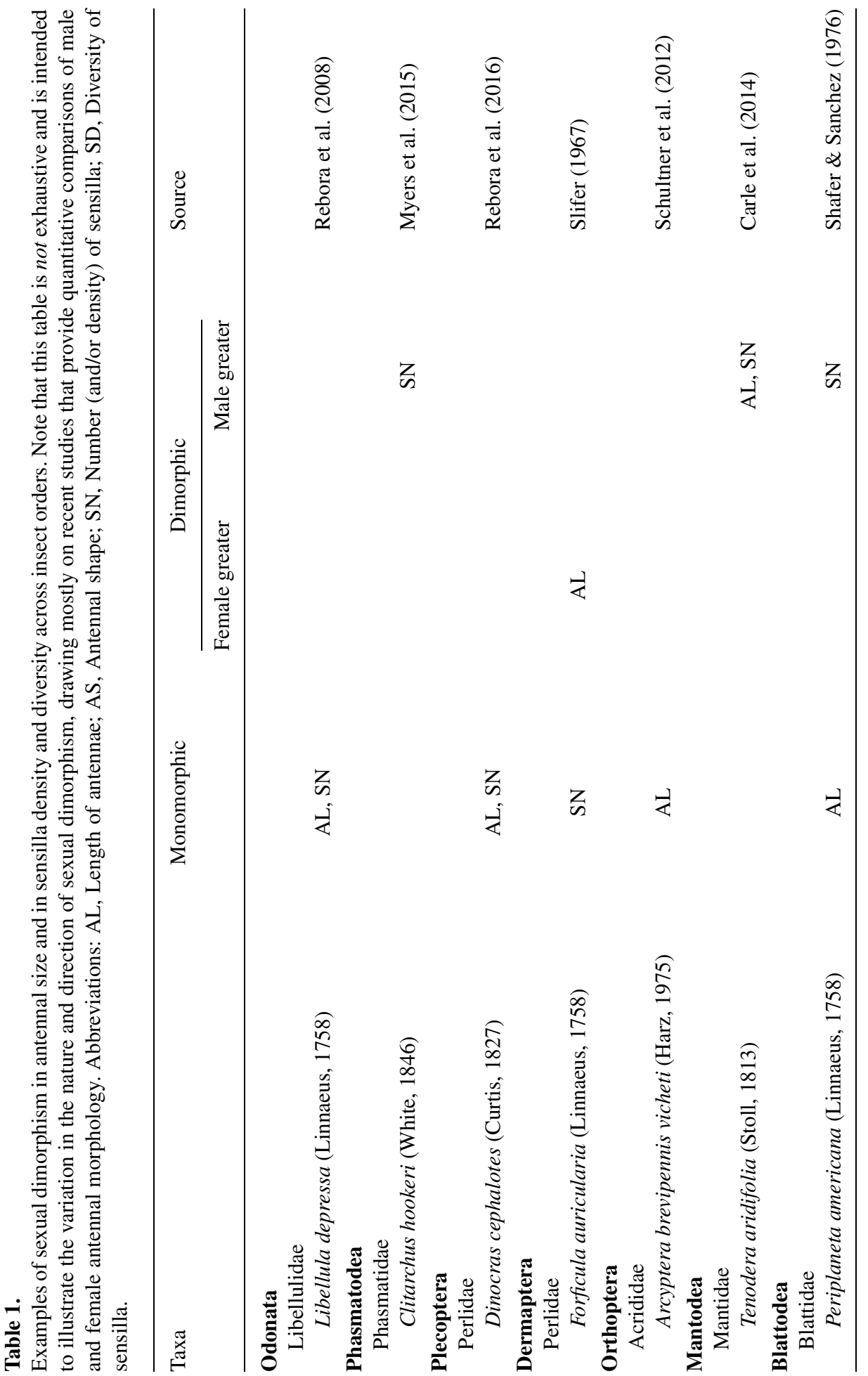




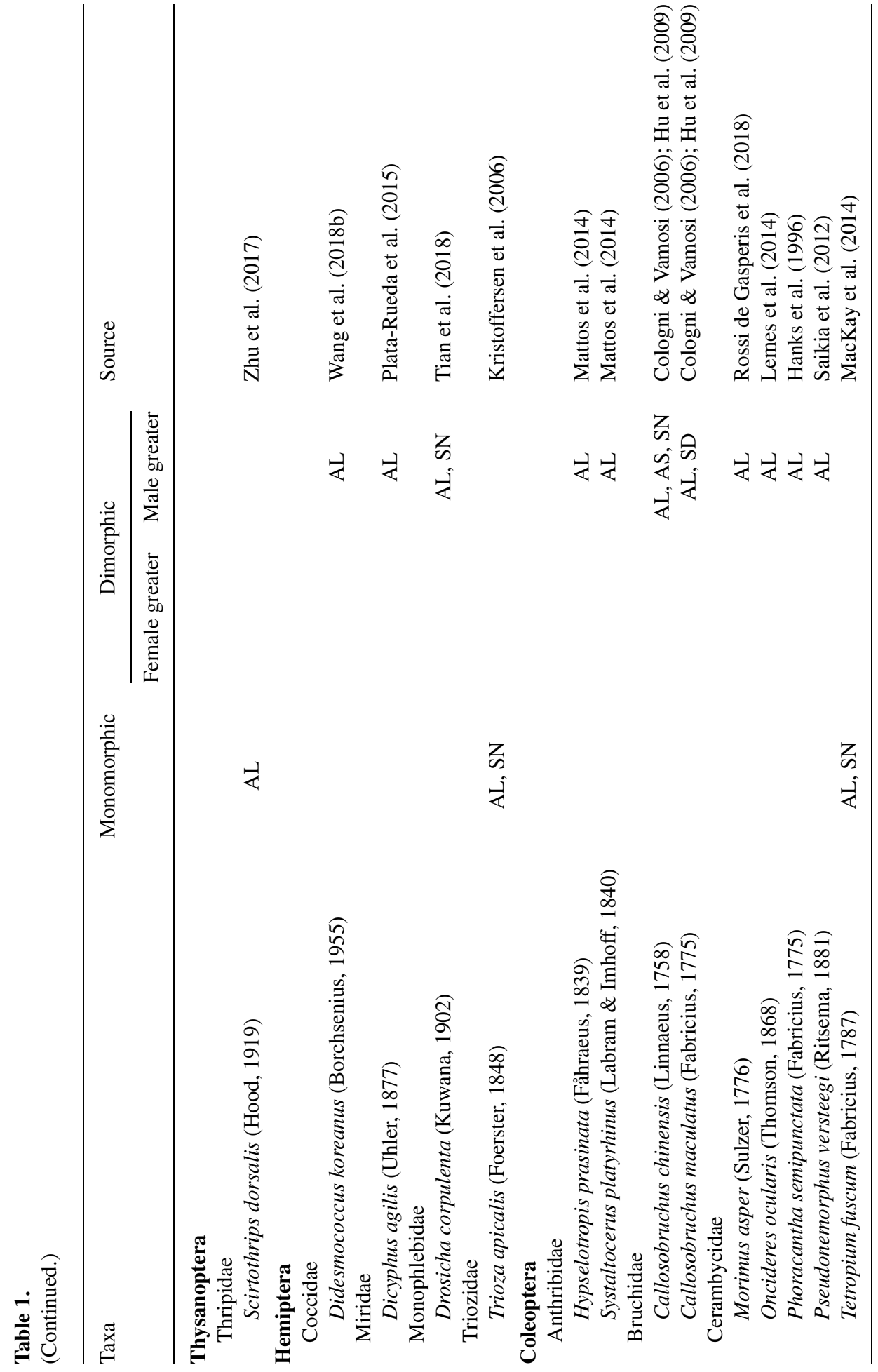


M.A. Elgar et al. / Animal Biology 69 (2019) 63-82

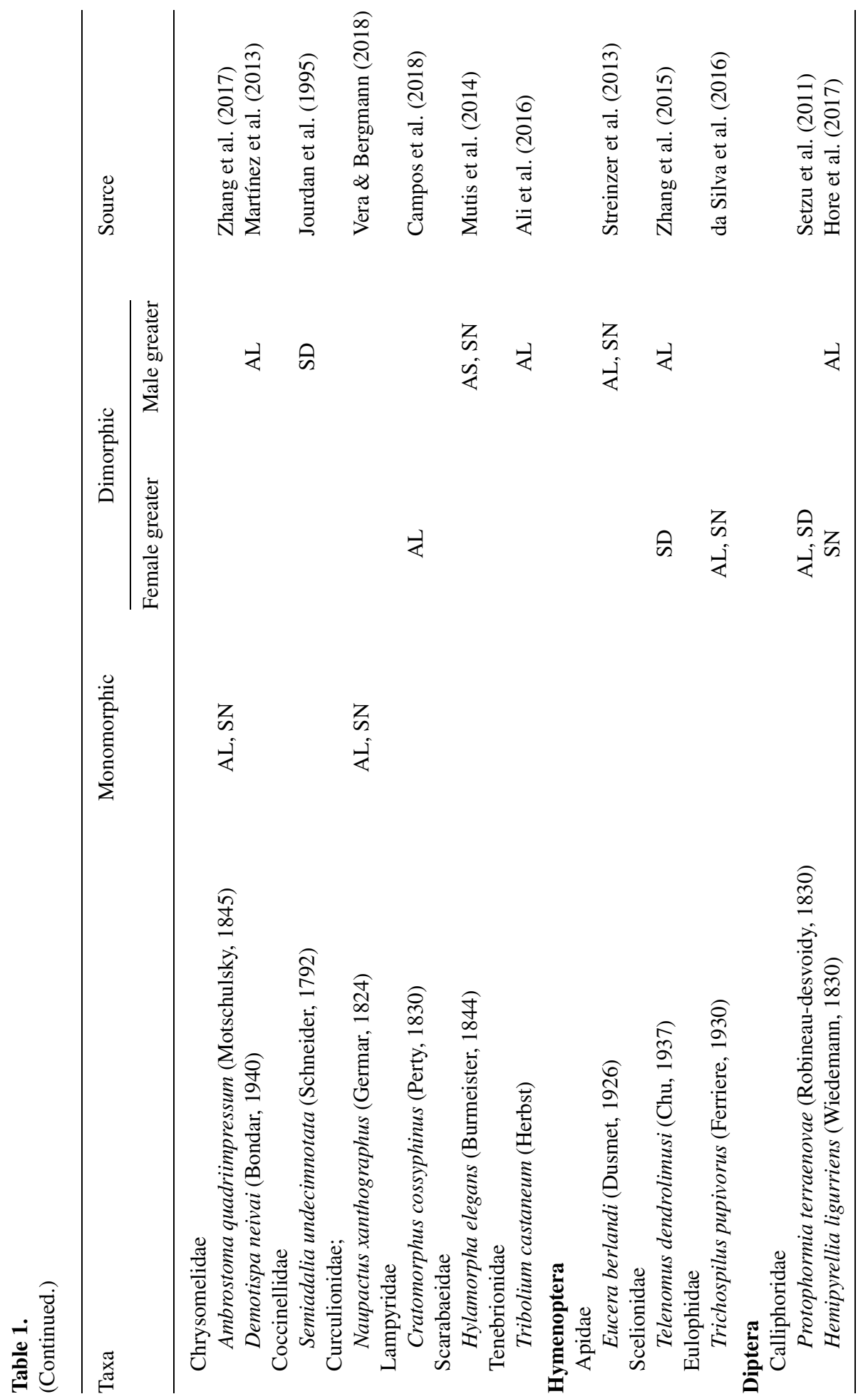




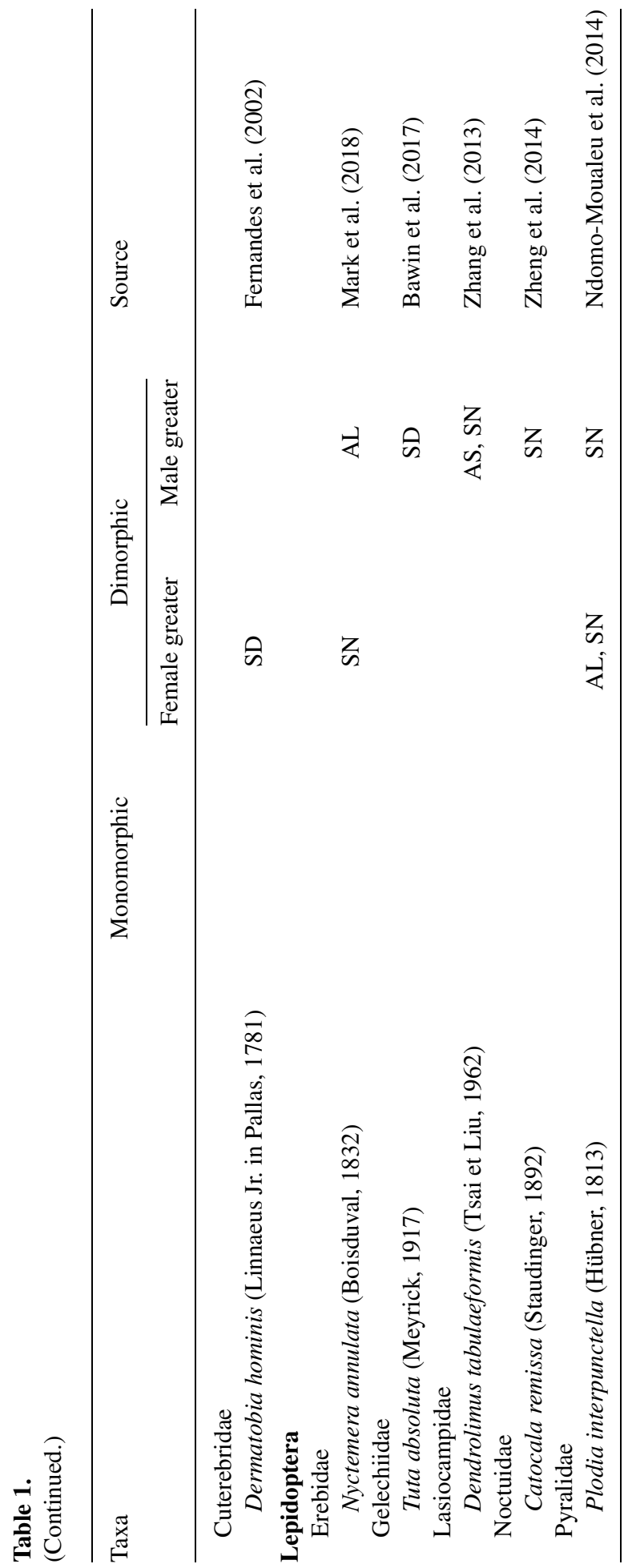




\section{Sexual selection}

Darwin proposed his theory of sexual selection to explain the remarkable sexual dimorphism in secondary sexual characteristics, such as the extravagant plumage of male birds, or the deadly armaments of male mammals and insects (Darwin, 1871; Andersson, 1994; Andersson \& Simmons, 2006). Both reflect the intense competition among members of one sex, typically males, for mating opportunities with the other sex. Darwin identified two mechanisms of sexual selection - female choice, in which the female distinguishes between males according to morphological, physiological, behavioural and olfactory traits; and male-male competition, in which males use their armaments to physically defend sexually receptive females from rival males (Darwin, 1871). Although the initial focus was on traits associated with improving mating success, it is now clear that sexual selection can continue after mating, leading to male traits that favour paternity protection or female traits that favour polyandry (e.g., Simmons, 2001; Arnqvist \& Rowe, 2005). The role of sexual selection, and especially mate choice, in favouring the evolution of extravagant secondary sexual characteristics has been extensively documented (Darwin, 1871; Andersson, 1994; Andersson \& Simmons, 2008; Rosenthal, 2017).

A vexing question for understanding sexual selection is why females might prefer to mate with males with more extravagant secondary sexual characteristics. The emerging consensus is that these secondary sexual characteristics act as signals, providing females with information about the relative quality of males they encounter (Andersson \& Simmons, 2008; Rosenthal, 2017). This quality may reflect the ability of males to provide material benefits, such as parental care of their offspring, or more generalised abilities that are determined by their genotype (Andersson $\&$ Simmons, 2008). The signals provide accurate information because they are costly, thereby allowing females to make a judicious choice of the sire of their offspring: malnourished or diseased males would have fewer resources available to invest in extravagant signals than their well-nourished, pathogen-resistant counterparts. Signals of male mate quality have been identified in most sensory modalities, but especially in visual and acoustic channels (Rosenthal, 2017).

\section{Darwin's neglected idea}

The role of sexual selection in the evolution of extravagant male signals has captured the imagination of evolutionary and behaviour ecologists, resulting in a plethora of theoretical and empirical studies. It is therefore surprising that Darwin's suggestion that sexual selection will act on the morphology of 'organs of sense' has been largely overlooked, despite this source of sexual dimorphism being highlighted on the first page of his introduction to sexual selection:

"But the sexes often differ in what Hunter has called secondary sexual characters, which are not directly connected with the act of reproduction; for instance, 
in the male possessing certain organs of sense or locomotion, of which the female is quite destitute, or in having them more highly-developed, in order that he may readily find or reach her." (Darwin, 1871, p. 253)

Indeed, Darwin specifically mentions these characteristics when he explains why it is necessary to introduce the role of sexual selection in the evolution of sexual dimorphism:

"When the two sexes follow exactly the same habits of life, and the male has more highly developed sense or locomotive organs than the female, it may be that these in their perfected state are indispensable to the male for finding the female; but in the vast majority of cases, they serve only to give one male an advantage over another, for the less well-endowed males, if time were allowed them, would succeed in pairing with the females; and they would in all other respects, judging from the structure of the female, be equally well adapted for their ordinary habits of life. In such cases sexual selection must have come into action, for the males have acquired their present structure, not from being better fitted to survive in the struggle for existence, but from having gained an advantage over other males, and from having transmitted this advantage to their male offspring alone. It was the importance of this distinction which led me to designate this form of selection as sexual selection." (Darwin, 1871, p. 257)

There may be many reasons why this remarkable idea has been largely ignored, especially in the context of insect antennae as an 'organ of sense'. First, the significance of antennae for detecting volatile odours, or pheromones, was not known at that time. For example, the role of antennae in allowing ants to discriminate between the odours of nestmates and others is now well understood (Wang et al., 2016), but this was not the case when Darwin first proposed sexual selection. Another 15 years passed before this function was revealed to the renowned entomologist AugusteHenri Forel, who excised on the 12th August, 1886, the antennae of workers of different species and placed them together in a container, where they "huddled piously together" rather than displaying a more typical aggressive response (Forel, 1928). It is common knowledge that female moths release minute quantities of pheromone that are nevertheless capable of attracting males from several kilometres (Foster, 2016), but early researchers thought it impossible that any signal could be involved, and even suggested supernatural abilities akin to telepathy (Riley, 1895). Eventually, Fabre concluded that the source of attraction of male emperor moths to virgin females was chemical (Fabre, 1911). This lack of knowledge may explain why Darwin concluded that he was not especially concerned about sexually dimorphic organs of sense, despite their taxonomic reach. Instead, his focus was on females appreciating not just the musical tones of conspecific male homopterans and orthopterans, but also the beauty in form or colour of other insects (Darwin, 1971).

Darwin clearly recognised the challenge of distinguishing between the role of natural and sexual selection in the evolution of 'organs of sense', and this may also explain why his interest lay more strongly on other forms of sexual dimorphism. 
Darwin addressed this issue explicitly, highlighting the conditions under which natural or sexual selection might apply:

"As the male has to search for the female, he requires for this purpose organs of sense and locomotion, but if these organs are necessary for the other purposes of life, as is generally the case, they will have been developed through natural selection." (Darwin, 1971, p. 257)

The potential ambiguity over the role of natural and sexual selection in shaping the 'organ of sense' may also have encouraged others to investigate the more obvious manifestations of sexual selection. Interestingly, in a review of insect mating behaviour, Lloyd (1979a) reiterated Darwin's view that males with longer antennae will have greater mating success than those with shorter antennae, but inferred the action of natural, rather than sexual selection. An extensive review of the role of chemical communication in sexual selection in moths (Svensson, 1996) did not mention Darwin's idea, and Allen et al. (2011) suggested that sexual dimorphism in the sensory structures of lepidopterans is shaped by predator-mediated natural selection. Indeed, our understanding of the role of mate choice in sexual selection is informed primarily from research on the adaptive value of the signal, and especially the relationship between the signal and the signaller (Maynard Smith \& Harper, 2003; Searcy \& Nowicki, 2005; Stevens, 2013). Reference to the receiver is typically couched in terms of how the signal is distinguished from the background (e.g., Endler, 1978), rather than variation in the acuity of the receiver (e.g., Gill et al., 2013).

An important assumption underlying Darwin's prediction is that antennal morphology will determine the individual's capacity to detect a signal and respond appropriately. Numerous studies document the number, distribution and diversity of sensilla on insect antennae (Schneider, 1964; Elgar et al., in press), including in the context of different life-history attributes (e.g., Wcislo, 1995; Spaethe et al., 2007; Wittwer et al., 2018). However, the remarkably few investigations of whether natural variation in antennal morphology influences signal detection and behaviour are confined to studies of nest-mate recognition in ants (Gill et al., 2010), mate search in praying mantids (Jayaweera \& Barry, 2017; see also Holwell et al., 2007), and food choice in grasshoppers (Opstad et al., 2004).

\section{Discreet sex pheromones}

Sexually receptive animals may produce sex pheromones that are used to advertise the location of the signaller (Symonds \& Elgar, 2008; Wyatt, 2014). There is increasing interest in the role of these chemical signals in sexual selection, through providing information about the signaller's suitability as a mate (Johannson \& Jones, 2007; Symonds \& Elgar, 2008; Kelly et al., 2012; Steiger \& Stökl, 2014; Wyatt, 2014; Ingleby, 2015). For example, female cockroaches Nauphoeta cinerea (Olivier, 1789) use quantitative and qualitative differences in pheromones to distinguish between males (Moore \& Moore, 1999), and males of the orb-spider Argiope 
keyserlingi Karsch, 1878 use odours on the silk of the female's web to distinguish between females from local and distant populations (Henneken et al., 2015). More significantly, Thomas \& Simmons (2009) demonstrate that sexual selection acts on the cuticular hydrocarbon profile of the field cricket Teleogryllus oceanicus (Le Guillou, 1841), and Harari et al. (2011) document a fitness cost of pheromone production in signalling moths.

In many insects, but especially moths, it is typically the female that releases these olfactory signals to which the males respond, suggesting that this represents a rolereversal in the context of sexual selection - with males using these sex pheromones as a means of discriminating among conspecific females (e.g., Greenfield, 2016). An alternative interpretation is that the signals simply identify the location of a receptive female, and females may indirectly benefit through the subsequent scramble competition (Lloyd, 1979b).

However, it is remarkable how little pheromone is released by the female. One explanation is that this has a winnowing effect - ensuring that females emitting a low, rather than high pheromone titre are discovered only by males with greater olfactory sensitivity (Lloyd, 1979b; Greenfield, 1981). While Lloyd (1979a) suggests that selection acts on 'organs of sense', he argues that natural, rather than sexual selection favours this 'winnowing' process. Thus, passive filtering is distinguished from passive selection: in the former, the "up-wind flight toward a female becomes a race, not merely a trip" (Lloyd, 1979b, p. 297), and this differs from active filtering, where the behaviour of the female may inhibit or facilitate copulation. Females may adjust the degree of active filtering, by making it easier or harder for males to find them, depending upon their likelihood of securing a mate: young virgin females may be more selective than older virgin females, and may adjust the degree of filtering by varying the duration or timing of releasing their pheromone signal (Lloyd, 1979b; see also Umbers et al., 2015).

These ideas assume that males with greater olfactory sensitivity will also be 'superior' in other ways and thus make an attractive sire, although the underlying mechanism is not articulated. Greenfield (2016) subsequently provides several reasons for doubting this process: in particular, females risk remaining unmated, because males may fail to detect the pheromone plumes, and that the low pheromone titre may simply reflect physiological constraints (Foster, 2009). Additionally, delays in attracting males may decrease female reproductive output by reducing the time available to locate and oviposit on suitable host plants. However, there is increasing evidence that females generally increase their signalling effort, measured as pheromone titre or time spent 'calling', with age (Umbers et al., 2015).

\section{Female choice: linking discreet signalling with extravagant organs of sense}

Females that reduce their calling rate or titre of sex pheromones may benefit by mating with high-quality males, if their signalling investment results in sexual selection favouring larger or more sensitive male antennae, and if these large antennae 
are costly to develop and maintain. Thus, as the quality of the male determines the extent of his investment in secondary sexual characteristics (Higham, 2014), so too does the quality of the male determine his ability to invest in sensory receptor organs (antennae). Several lines of evidence are required to support this idea: (i) receptor organs are costly; (ii) an association between pheromone detection and receptor organ morphology; (iii) an association between male quality and investment in receptor organs; and (iv) strategic signalling in females.

\section{Receptor organs are costly}

It is widely recognised that nervous tissue is among the most expensive of animal tissues (Niven \& Laughlin, 2008; Stöckl et al., 2016) and so selection is expected to optimise investment in receptor organ morphology by balancing the benefits of improved signal perception against the costs of developing and maintaining these structures. The most obvious manifestation of these costs is the sexual dimorphism in antennal morphology, where selection favours dis-investment in sensory receptors if there is less reward on signal detection or there are fewer odours to detect, resulting in the signalling sex having smaller or less extravagant antennae. Adult grasshoppers reared on synthetic diets with fewer flavours or odours had lower numbers of sensilla (Rogers \& Simpson, 1997; Bernays \& Chapman, 1998), presumably reflecting a redundancy in sensory requirements. Similar patterns have been documented for social signals, where evolutionary transitions from social to solitary lifestyles in halictid bees are accompanied by lower investment in antennal sensilla (Wittwer et al., 2017). Studies of anticipatory life-history investment also provide insights into the costs of receptor organ development. Adult males of the leaf skeletoniser moth Uraba lugens Walker, 1866 that were raised as larvae in high densities had smaller antennae (but larger testes) than those reared at a low density, presumably because it is easier to locate a mate when the adult population is dense, but this also increases the risk of sperm competition (Johnson et al., 2017a). This anticipatory flexibility in sensory investment may explain why there was no evolutionary response in antennal morphology to long-term selection through population density in the Indian meal moth Plodia interpunctella Guenée, 1845 (Ashman et al., 2016).

More direct identification of the costs of neural activity is highlighted in studies of learning in insects. The fitness costs of learning may derive from allocating resources required in the development and maintenance of neural structures, and from allocating resources to the process of learning (Burns et al., 2011). Selection experiments that examine evolutionary trade-offs provide evidence of the former, where selection for learning ability results in reduced larval competitive ability (Mery \& Kawecki, 2003; Kolss \& Kawecki, 2008), adult longevity (Burger et al., 2008), and oxidative stress resistance (Amdam et al., 2010). Evidence for the latter comes from experiments demonstrating that the longevity of flies was reduced if they engaged in activities involving long-term memory (Mery \& Kawecki, 2004). 


\section{Pheromone detection and receptor organ morphology}

Several studies provide indirect support for Darwin's (1871) key prediction that mating success is positively correlated with the size of the receptor organ. In some populations of the Australian pollen katydid Kawanaphila nartee Rentz, 1993, females compete for mating opportunities with males, and the size of auditory spiracles on the thorax of females influenced their sensitivity to male calls (Gwynne \& Bailey, 1999). Field experiments revealed that the first females to reach the male (over relatively short distances) had larger spiracles and thus greater sensitivity to calls (e.g., Requena verticalis Walker, 1869 - Bailey, 1998) than did their rivals, a pattern that was independent of female body size (Gwynne \& Bailey, 1999). In field populations, male long-horned beetles Phoracantha semipunctata (Fabricius, 1775) that mated were larger and had longer antennae than unmated males: males rely on their antennae to contact females on the host tree, and the larger antennae of large males allow them to search more efficiently (Hanks et al., 1996). Laboratory mate choice experiments revealed that females of the leaf-roller moth Cnephasia jactatana Walker, 1863 were more likely to mate with males with longer antennae (Jiménez-Pérez \& Wang, 2004), although this may not reflect detection ability, given the small $(6.5$ by $8.5 \mathrm{~cm})$ size of the containers and the potential confound with body size. Experiments with captive false garden mantids Pseudomantis albofimbriata (Stål, 1860) revealed a negative correlation between the time taken to arrive at a calling female and the number of trichoid sensilla, but not with the number of other sensilla or male body and wing size (Jayaweera \& Barry, 2017). In contrast, body size was a stronger predictor of mating success than antennal length in natural populations of the water louse Asellus aquaticus (Linnaeus, 1758) (Isopoda) (Bertin \& Cézilly, 2003), and while males with longer antennae had greater mating success at low- but not in high-density captive populations, as might be expected, males with longer antennae were not typically faster at locating a female (Bertin \& Cézilly, 2005). The correlational nature of these studies means that it is not clear whether other traits may also be involved in male mating success. Nevertheless, Yan et al. (2014) report that the mating rate of male diamondback moths Plutella xylostella (Linnaeus, 1758) is reduced if their filiform antennae are experimentally shortened (see also Bertin \& Cézilly, 2003), although these experimental procedures may have affected the behaviour of the moths more generally (see Peng et al., 2018).

Johnson et al. (2017b) accounted for this problem by experimentally manipulating the quantity of sex pheromone released by females of $U$. lugens. Males of these moths have bipectinate antennae, while females have simple filiform antennae. Johnson et al. (2017b) conducted a field experiment, in which either one or two females were restrained in delta traps. The size of the antennae of males that were subsequently caught in the traps was then measured. While similar numbers of males were caught in the two traps, males from traps baited with one female had significantly longer antennae than males found in traps baited with two females. 
These results are broadly consistent with Darwin's (1871) prediction that sexual selection favours larger sensory receptor organs: males with longer antennae are more likely to detect and respond to the pheromone produced by a single female.

These studies provide encouraging support for Darwin's (1871) prediction, in terms of the size of the receptor organ or the number of sensilla it supports. These patterns may also be evident for other features of the morphology of receptor organs. For example, Wang et al. (2018a) show that the arrangement of scales on the filiform antennae of moths can influence the likelihood of the pheromone interacting with the receptors on the sensilla. Perhaps these and other micro-morphological features including the size and abundance of sensilla are also subject to sexual selection.

\section{Male quality and receptor organ morphology}

While the relationship between male quality and sexual signals has been investigated extensively (Rosenthal, 2017), few studies specifically evaluate the relationship between male quality and receptor organ morphology. The length of antennae of the neriid fly Telostylinus angusticollis (Enderlein, 1922) is sexually dimorphic, and Bonduriansky (2007) showed that the size of male antennae responds more strongly to the effects of condition (larval diet quality) than that of female antennae. Perhaps antennal traits, including the size and density of olfactory sensilla, are more variable in males than in females, especially in species under strong sexual selection.

One potential avenue to address this question is to utilise the links between individual fitness, developmental stability and fluctuating asymmetry, the small differences in bilaterally symmetrical structures that can include sensory organs like antennae (van Dongen, 2008). Several studies report correlations between patterns of mating success and symmetry in antennal length. Mated males and females of the cerambycid beetle Stenurella melanura (Linnaeus, 1758) have more symmetrical antennae than unmated males and females (Møller \& Zamora-Muñoz, 1997). Likewise, the mating success of male white-tailed zygaenid moths Elcysma westwoodii (Snellen van Vollenhoven, 1863) decreases with increasing antennal asymmetry (Koshio et al., 2007). However, whether the developmental stability, reflected by measures of fluctuating asymmetry, of sexually selected ornaments reveals male genetic quality remains uncertain (Polak, 2008; van Dongen, 2008). Organs of sense, which are both costly and crucial, may be excellent candidate traits: several studies report increased asymmetry in antennal size of insects that are subject to environmental stressors (Müller et al., 2017; but see Labrie et al., 2003).

\section{Strategic signalling by females}

Theory predicts that females adjust the quantity of pheromone used each day by balancing the risk of not attracting a male against age-specific mortality, with females commencing signalling at a low rate, and unmated females increasing that effort as 
they age (Umbers et al., 2015; see also Lloyd, 1979b). The results of the field experiments conducted by Johnson et al. (2017b) suggest that female signalling effort is directed more to attracting particular kinds rather than numbers of males. Thus, females can exercise mate choice by signalling not through some form of sex-role reversal, but rather through the action of sexual selection on the morphology of male organs of sense.

\section{Concluding remarks}

Darwin described how sexual selection can act on 'organs of sense', such as insect antennae, if it provides male receivers with a competitive edge over locating receptive female signallers. His idea, with its focus on male-male competition, has attracted remarkably little attention, but recent evidence that pheromone detection is linked with antennal morphology is consistent with his view. Sexual selection on antennal morphology, including the size and abundance of sensilla, may also act through female choice because receptor organs are costly and could reflect male condition. Currently missing is evidence that females adjust their signalling effort to attract particular kinds of males, rather than just males. It is time to revisit Darwin's neglected idea.

\section{Acknowledgements}

Our work on the evolution of insect antennal diversity is supported by the Australian Research Council (grants DP0879610, DP0987360, DP120100162 to MAE), the Holsworth Wildlife Fund (to TLJ) and the University of Melbourne Scholarships scheme (to TLJ). We thank two referees for their helpful comments.

\section{References}

Ali, S.A.I., Diakite, M.M., Ali, S. \& Wang, M.-Q. (2016) Effects of the antennal sensilla distribution pattern on the behavioral responses of Tribolium castaneum (Coleoptera: Tenebrionidae). Florida Entomol., 99, 52-59.

Allen, C.E., Zwaan, B.J. \& Brakefield, P.M. (2011) Evolution of sexual dimorphism in the Lepidoptera. Annu. Rev. Entomol., 56, 445-464.

Amdam, G.V., Fennern, E., Baker, N. \& Rascón, B. (2010) Honeybee associative learning performance and metabolic stress resilience are positively associated. PLoS One, 5, e9740. DOI:10. 1371/journal.pone.0009740.

Andersson, M. (1994) Sexual Selection. Princeton University Press, Princeton, NJ, USA.

Andersson, M. \& Simmons, L.W. (2006) Sexual selection and mate choice. Trends Ecol. Evol., 21, 296-302.

Arnqvist, G. \& Rowe, L. (2005) Sexual Conflict. Princeton University Press, Princeton, NJ, USA.

Ashman, K.R., McNamara, K.B. \& Symonds, M.R.E. (2016) Experimental evolution reveals that population density does not affect moth signalling behaviour and antennal morphology. Evol Ecol., 30, 1009-1021. 
Bailey, W.J. (1998) Do large bushcrickets have more sensitive ears? Natural variation in hearing thresholds within populations of the bushcricket Requena verticalis (Listroscelidinae: Tettigoniidae). Physiol. Entomol., 23, 105-112.

Bawin, T., Collard, F., De Backer, L., Yarou, B.B., Compère, P. \& Verheggen, F.J. (2017) Structure and distribution of the sensilla on the antennae of Tuta absoluta (Lepidoptera: Gelechiidae). Micron, 96, 16-28.

Bernays, E.A. \& Chapman, R.F. (1998) Phenotypic plasticity in numbers of antennal chemoreceptors in a grasshopper: effects of food. J. Comp. Physiol. A, 183, 69-76.

Bertin, A. \& Cézilly, F. (2003) Sexual selection, antennal length and the mating advantage of large males in Asellus aquaticus. J. Evol. Biol., 16, 698-707.

Bertin, A. \& Cézilly, F. (2005) Density-dependent influence of male characters on mate-locating efficiency and pairing success in the waterlouse Asellus aquaticus: an experimental study. J. Zool. (Lond.), 265, 333-338.

Bonduriansky, R. (2007) The evolution of condition-dependent sexual dimorphism. Am. Nat., 169, 9-19.

Burger, J.M.S., Kolss, M., Pont, J. \& Kawecki, T.J. (2008) Learning ability and longevity: a symmetrical evolutionary trade-off in Drosophila. Evolution, 62, 1294-1304.

Burns, J.G., Foucaud, J. \& Mery, F. (2011) Costs of memory: lessons from 'mini' brains. Proc. R. Soc. B, 278, 923-929.

Campos, S.V.N., da Silveira, L.F.L. \& Mermudes, J.R.M. (2018) Systematic review of the giant firefly Cratomorphus cossyphinus: sexual dimorphism, immature stages and geographic range (Coleoptera: Lampyridae). Ann. Zool., 68, 57-84.

Carle, T., Yamawaki, Y., Watanabe, H. \& Yokohari, F. (2014) Antennal development in the praying mantis (Tenodera aridifolia) highlights multitudinous processes in hemimetabolous insect species. PLoS One, 9, e98324. DOI:10.1371/journal.pone.0098324.

Chapman, R.F. (1982) Chemoreception: the significance of receptor numbers. Adv. Insect Physiol., $16,247-356$.

Colgoni, A. \& Vamosi, S.M. (2006) Sexual dimorphism and allometry in two seed beetles (Coleoptera: Bruchidae). Entomol. Sci., 9, 171-179.

da Silva, I.M., de Sousa Pereira, K., Spranghers, T., Zanuncio, J.C. \& Serrão, J.E. (2016) Antennal sensilla and sexual dimorphism of the parasitoid Trichospilus pupivorus (Hymenoptera: Eulophidae). Microsc. Microanal., 22, 913-921.

Darwin, C. (1871) The Descent of Man and Selection in Relation to Sex. Murray, London, UK.

Elgar, M.A., Zhang, D., Wang, Q., Wittwer, B., Pham, H., Johnson, T.L., Freelance, C.B. \& Coquilleau, M. (in press) Insect antennal morphology: the evolution of diverse solutions to odorant perception. Yale J. Biol. Med.

Endler, J.A. (1978) A predator's view of animal color patterns. Evol. Biol., 11, 319-364.

Fabre, J.H. (1911) Social Life in the Insect World. Penguin, Harmondsworth, UK.

Fernandes, F. de F., Linardi, P.M. \& Chiarini-Garcia, H. (2002) Morphology of the antenna of Dermatobia hominis (Diptera: Cuterebridae) based on scanning electron microscopy. J. Med. Entomol., 39, 36-43.

Forel, A. (1928) The Social World of the Ants, 2 vols., C.K. Ogden (transl.). G. P. Putnam's Sons, London, UK.

Foster, S.P. (2009) Sugar feeding via trehalose haemolymph concentration affects sex pheromone production in mated Heliothis virescens moths. J. Exp. Biol., 212, 2789-2794. 
Foster, S.P. (2016) Toward a quantitative paradigm for sex pheromone production in moths. In: J.D. Allison \& R.T. Cardé (Eds) Pheromone Communication in Moths, pp. 113-126. University of California Press, Oakland, CA, USA.

Gill, K.P., van Wilgenburg, E., Macmillan, D. \& Elgar, M.A. (2013) Density of sensilla influences efficacy of communication. Am. Nat., 182, 834-840.

Greenfield, M.D. (1981) Moth sex pheromones: an evolutionary perspective. Florida Entomol., 64, 4-17.

Greenfield, M.D. (2016) Sexual selection. In: J.D. Allison \& R.T. Cardé (Eds) Pheromone Communication in Moths, pp. 79-88. University of California Press, Oakland, CA, USA.

Gwynne, D.T. \& Bailey, W.J. (1999) Female-female competition in katydids: sexual selection for increased sensitivity to a male signal? Evolution, 53, 546-551.

Hanks, L.M., Millar, J.G. \& Paine, T.D. (1996) Body size influences mating success of the eucalyptus longhorned borer (Coleoptera: Cerambycidae). J. Insect Behav., 9, 369-382.

Harari, A.R., Zahavi, T. \& Thiery, D. (2011) Fitness cost of pheromone production in signaling female moths. Evolution, 65, 1572-1582.

Henneken, J., Jones, T.M., Goodger, J.Q.D., Walter, A. \& Elgar, M.A. (2015) Diet influences female signals used in male mate choice. Anim. Behav., 108, 215-221.

Higham, J. (2014) How does honest costly signalling work? Behav. Ecol., 25, 8-11.

Holwell, G.I., Barry, K.L. \& Herberstein, M.E. (2007) Mate location, antennal morphology, and ecology in two praying mantids (Insecta: Mantodea). Biol. J. Linn. Soc., 91, 307-313.

Hore, G., Maity, A., Naskar, A., Ansar, W., Ghosh, S., Sahae, G.K. \& Banerjee, D. (2017) Scanning electron microscopic studies on antenna of Hemipyrellia ligurriens (Wiedemann, 1830) (Diptera: Calliphoridae) - a blow fly species of forensic importance. Acta Trop., 172, 20-28.

Hu, F., Zhang, G.-N. \& Wang, J.-J. (2009) Scanning electron microscopy studies of antennal sensilla of bruchid beetles, Callosobruchus chinensis (L.) and Callosobruchus maculatus (F.) (Coleoptera: Bruchidae). Micron, 40, 320-326.

Ingelby, F.C. (2015) Insect cuticular hydrocarbons as dynamic traits in sexual communication. Insects, $6,732-742$.

Jayaweera, A. \& Barry, K.L. (2017) Male antenna morphology and its effect on scramble competition in false garden mantids. Sci. Nat., 104, 75. DOI:10.1007/s00114-017-1494-0.

Jiménez-Pérez, A. \& Wang, Q. (2004) Sexual selection in Cnephasia jactatana (Lepidoptera: Tortricidae) in relation to age, virginity and body size. Ann. Entomol. Soc. Am., 97, 819-824.

Johansson, B.G. \& Jones, T.M. (2007) The role of chemical communication in mate choice. Biol. Rev., 82, 265-289.

Johnson, T.L., Symonds, M.R.E. \& Elgar, M.A. (2017a) Anticipatory flexibility: larval population density in moths determines male investment in antennae, wings and testes. Proc. R. Soc. B, 284, 20172087. DOI:10.1098/rspb.2017.2087.

Johnson, T.L., Symonds, M.R.E. \& Elgar, M.A. (2017b) Sexual selection on receptor organ traits: younger females attract males with longer antennae. Sci. Nat., 104, 44. DOI:10.1007/s00114-0171466-4.

Jourdan, H., Barbier, R., Bernard, J. \& Ferran, A. (1995) Antennal sensilla and sexual dimorphism of the adult ladybird beetle Semiadalza undecimnotata Schn. (Coleoptera: Coccinellidae). Int. J. Insect Morphol. Embryol., 24, 307-322.

Kelly, C.A., Norbutus, A.J., Lagalante, A.F. \& Iyengar, V.K. (2012) Male courtship pheromones as indicators of genetic quality in an arctiid moth (Utetheisa ornatrix). Behav. Ecol., 23, 1009-1014.

Kolss, M. \& Kawecki, T.J. (2008) Reduced learning ability as a consequence of evolutionary adaptation to nutritional stress in Drosophila melanogaster. Ecol. Entomol., 33, 583-588. 
Koshio, C., Muraji, M., Tatsuta, H. \& Kudo, S. (2007) Sexual selection in a moth: effect of symmetry on male mating success in the wild. Behav. Ecol., 18, 571-578.

Kristoffersen, L., Hallberg, E., Wallén, R. \& Anderbrant, O. (2006) Sparse sensillar array on Trioza apicalis (Homoptera, Triozidae) antennae - an adaptation to high stimulus levels? Arthropod Struct. Dev., 35, 85-92.

Labrie, G., Prince, C. \& Bergeron, M.-M. (2003) Abundance and developmental stability of Pterostichus melanarius (Coleoptera: Carabidae) in organic and integrated pest management orchards of Quebec, Canada. Environ. Entomol., 32, 123-132.

Lemes, P.G., dos Anjos, N., Jorge, I.R. \& Cordeiro, G. (2014) Sexual dimorphism in the twig girdler Oncideres ocularis Thomson (Coleoptera: Cerambycidae). Entomol. News, 123, 358-364.

Lloyd, J.E. (1979a) Mating behavior and natural selection. Florida Entomol., 62, 17-34.

Lloyd, J.E. (1979b) Sexual selection in luminescent beetles. In: M.S. Blum \& N.A. Blum (Eds) Sexual Selection and Reproductive Competition in Insects, pp. 293-342. Academic Press, New York, NY, USA.

MacKay, C.A., Sweeney, J.D. \& Killier, N.K. (2014) Morphology of antennal sensilla of the brown spruce longhorn beetle, Tetropium fuscum (Fabr.) (Coleoptera: Cerambycidae). Arthropod Struct. Dev., 43, 469-475.

Mankin, R.W. \& Mayer, M.S. (1984) The insect antenna is not a molecular sieve. Experientia, 40, 1251-1252.

Mark, C.J., Parsons, S. \& Holwell, G.I. (2018) Antennal morphology and micro-sensory architecture of the New Zealand magpie moth, Nyctemera annulata (Lepidoptera: Erebidae): diversity, distribution and dimorphism. Austral Entomol., 54, 303-323.

Martínez, L.C., Plata-Rueda, A., Zanuncio, J.C., Leite, G.L.D. \& Serrão, J.E. (2013) Morphology and morphometry of Demotispa neivai (Coleoptera: Chrysomelidae) adults. Ann. Entomol. Soc. Am., 106, 164-169.

Mattos, I., Mermudes, J.R.M. \& Moura, M.O. (2014) Dimorphism and allometry of Systaltocerus platyrhinus and Hypselotropis prasinata (Coleoptera: Anthribidae). Zoologia, 31, 51-62.

Maynard Smith, J. \& Harper, D.G.C. (2003) Animal Signals. Oxford University Press, Oxford, UK.

Mery, F. \& Kawecki, T.J. (2003) A fitness cost of learning ability in Drosophila melanogaster. Proc. R. Soc. Lond. B, 270, 2465-2469.

Mery, F. \& Kawecki, T.J. (2004) An operating cost of learning in Drosophila melanogaster. Anim. Behav., 68, 589-598.

Mohamedsaid, M.S. (2004) Modified antennae of Malaysian Galerucinae and its taxonomic significance. In: P. Jolivet, J.A. Santiago-Blay \& M. Schmitt (Eds) New Developments in the Biology of Chrysomelidae, pp. 231-247. SPB Academic Publishing, The Hague, The Netherlands.

Møller, A.P. \& Zamora-Muñoz, C. (1997) Antennal asymmetry and sexual selection in a cerambycid beetle. Anim. Behav., 54, 1509-1515.

Moore, A.J. \& Moore, P.J. (1999) Balancing sexual selection through opposing mate choice and male competition. Proc. R. Soc. Lond. B, 266, 711-716.

Müller, T., Prosche, A. \& Müller, C. (2017) Sublethal insecticide exposure affects reproduction, chemical phenotype as well as offspring development and antennae symmetry in a leaf beetle. Environ. Pollut., 230, 709-717.

Mutis, A., Palma, R., Parra, L., Alvear, M., Isaacs, R., Morón, M. \& Quiroz, A. (2014) Morphology and distribution of sensilla on the antennae of Hylamorpha elegans Burmeister (Coleoptera: Scarabaeidae). Neotrop. Entomol., 43, 260-265.

Myers, S.S., Buckley, T.R. \& Holwell, G.I. (2015) Mate detection and seasonal variation in stick insect mating behaviour (Phamatodea: Clitarchus hookeri). Behaviour, 152, 1325-1348. 
Ndomo-Moualeu, A.F., Christian Ulrichs, C., Renate Radek, R. \& Adler, C. (2014) Structure and distribution of antennal sensilla in the Indian meal moth, Plodia interpunctella (Hübner, 1813) (Lepidoptera: Pyralidae). J. Stored Prod. Res., 59, 66-75.

Niven, J.E. \& Laughlin, S.B. (2008) Energy limitation as a selective pressure on the evolution of sensory systems. J. Exp. Biol., 211, 1792-1804.

Opstad, R., Rogers, S.M., Behmer, S.T. \& Simpson, S.J. (2004) Behavioural correlates of phenotypic plasticity in mouthpart chemoreceptor numbers in locusts. J. Insect Physiol., 50, 725-736.

Peng, L., Chen, L., Li, J., Hou, Y. \& Chen, Y. (2018) Mate recognition and antennal morphology of Octodonta nipae (Coleoptera: Chrysomelidae) adults. J. Asia-Pacific Entomol., 21, 268-278.

Plata-Rueda, A., Martínez, L.C., Zanuncio, J.C. \& Serrão, J.E. (2015) Morphology and morphometry of Dicyphus agilis (Hemiptera: Miridae) adults. Ann. Entomol. Soc. Am., 108, 333-338.

Polak, M. (2008) The developmental instability - sexual selection hypothesis: a general evaluation and case study. Evol. Biol., 35, 208-230.

Ray, A.M., Ginzel, M.D. \& Hanks, L.M. (2009) Male Megacyllene robiniae (Coleoptera: Cerambycidae) use multiple tactics when aggressively competing for mates. Environ. Entomol., 38, 425-432.

Rebora, M., Piersanti, S. \& Gaino, E. (2008) The antennal sensilla of the adult of Libellula depressa (Odonata: Libellulidae). Arthropod Struct. Dev., 37, 504-510.

Rebora, M., Tierno de Figueroa, J.M. \& Piersanti, S. (2016) Antennal sensilla of the stonefly Dinocras cephalotes (Plecoptera: Perlidae). Arthropod Struct. Dev., 45, 552-561.

Riley, C.V. (1895) The senses of insects. Insect Life, 7, 33.

Rogers, S.M. \& Simpson, S.J. (1997) Experience-dependent changes in the number of chemosensory sensilla on the mouthparts and antennae of Locusta migratoria. J. Exp. Biol., 200, 2313-2321.

Rosenthal, G.G. (2017) Mate Choice: the Evolution of Sexual Decision Making from Microbes to Humans. Princeton University Press, Princeton, NJ, USA.

Rossi de Gasperis, S., De Zan, L.R., Romiti, F., Hardersen, S. \& Carpaneto, G.M. (2018) Sexual dimorphism and allometry of secondary sexual character in Morimus asper (Coleoptera: Cerambycidae). Zoomorphology, 137, 119-130.

Saikia, K., Thakur, N.S.A., Ao, A. \& Gautam, S. (2012) Sexual dimorphism in Pseudonemorphus versteegi (Ritsema) (Coleoptera: Cerambycidae), citrus trunk borer. Florida Entomol., 95, 625629.

Schneider, D. (1964) Insect antennae. Annu. Rev. Entomol., 9, 103-122.

Schultner, E., Blanchet, E., Pagès, C., Lehmann, G.U.C. \& Lecoq, M. (2012) Development, reproductive capacity and diet of the Mediterranean grasshopper Arcyptera brevipennis vicheti Harz 1975 (Orthoptera: Caelifera: Acrididae: Gomphocerinae). Ann. Soc. Entomol. Fr. (N.S.), 48, 299-307.

Searcy, W.A. \& Nowicki, S. (2005) Evolution of Animal Communication: Reliability and Deception in Signalling Systems. Princeton University Press, Princeton, NJ, USA.

Setzu, M.D., Poddighe, S. \& Angioy, A.M. (2011) Sensilla on the antennal funiculus of the blow fly, Protophormia terraenovae (Diptera: Calliphoridae). Micron, 42, 471-477.

Shafer, R. \& Sanchez, T.V. (1976) Nature and development of sex attractant specificity in cockroaches of genus Periplaneta. I. Sexual dimorphism in distribution of antennal sense-organs in five species. J. Morphol., 149, 139-157.

Simmons, L.W. (2001) Sperm Competition and Its Evolutionary Consequences in the Insects. Princeton University Press, Princeton, NJ, USA.

Slifer, E.H. (1967) Sense organs on antennal flagella of earwigs (Dermaptera) with special reference to those of Forficula auricularia. J. Morphol., 122, 63-79.

Spaethe, J., Brockmann, A., Halbig, C. \& Tautz, J. (2007) Size determines antennal sensitivity and behavioral threshold to odors in bumblebee workers. Naturwissenschaften, 94, 733-739. 
Steiger, S. \& Stökl, J. (2014) The role of sexual selection in the evolution of chemical signals in insects. Insects, 5, 423-438.

Stevens, M. (2013) Sensory Ecology, Behaviour, and Evolution. Oxford University Press, Oxford, UK.

Stöckl, A., Heinze, S., Charalabidis, A., el Jundi, B., Warrant, E. \& Kelber, A. (2016) Differential investment in visual and olfactory brain areas reflects behavioural choices in hawk moths. Sci. Rep., 6, 26041. DOI:10.1038/srep26041.

Streinzer, M., Kelber, C., Pfabigan, S., Kleineidam, C.H. \& Spaethe, J. (2013) Sexual dimorphism in the oldfactory system of a solitary and a eusocial bee species. J. Comp. Neurol., 521, 2742-2755.

Svensson, M. (1996) Sexual selection in moths: the role of chemical communication. Biol. Rev., 71, 113-135.

Symonds, M.R.E. \& Elgar, M.A. (2008) The evolution of pheromone diversity. Trends Ecol. Evol., 23, 220-228.

Symonds, M.R.E., Johnson, T.L. \& Elgar, M.A. (2012) Pheromone production, male abundance, body size, and the evolution of elaborate antennae in moths. Ecol. Evol., 2, 227-246.

Thomas, M.L. \& Simmons, L.W. (2009) Sexual selection on cuticular hydrocarbons in the Australian field cricket, Teleogryllus oceanicus. BMC Evol. Biol., 9, 162. DOI:10.1186/1471-2148-9-162.

Tian, X., Yu, H., Su, Q., Zhang, J., Li, C., Wang, W. \& Zhang, G. (2018) Sexual dimorphism of antenna of the scale insect Drosicha corpulenta (Kuwana) (Hemiptera: Coccoidae: Monophlebidae). Zool. Anz., 272, 65-72.

Tolasch, T., Kehl, S. \& Dötterl, S. (2012) First sex pheromone of the order Strepsiptera: (3R,5R,9R)-3,5,9-Trimethyldodecanal in Stylops melittae Kirby, 1802. J. Chem. Ecol., 38, 14931503.

Umbers, K.D.L., Symonds, M.R.E. \& Kokko, H. (2015) The mothematics of female pheromone signaling: strategies for aging virgins. Am. Nat., 185, 417-432.

van Dongen, S. (2008) Fluctuating asymmetry and developmental instability in evolutionary biology: past, present and future. J. Evol. Biol., 19, 1727-1743.

Vera, W. \& Bergmann, J. (2018) Distribution and ultrastructure of the antennal sensilla of the grape weevil Naupactus xanthographus (Coleoptera: Curculionidae). Microsc. Res. Tech., 81, 590-598.

Wang, Q., Goodger, J.Q.D., Woodrow, I.E. \& Elgar, M.A. (2016) Location-specific cuticular hydrocarbon signals. Proc. R. Soc. B, 283, 20160310. DOI:10.1098/rspb.2016.0310.

Wang, Q., Shang, Y., Hilton, D.S., Inthavong, K., Zhang, D. \& Elgar, M.A. (2018a) Antennal scales improve signal detection efficiency in moths. Proc. R. Soc. B, 285, 20172832. DOI:10.1098/rspb. 2017.28.

Wang, X., Xie, Y., Zhang, Y., Liu, W. \& Xiong, Q. (2018b) Antennal sensilla of Didesmococcus koreanus Borchsenius (Hemiptera: Coccoidea: Coccidae) in different instars. Zool. Anz., 274, 103114.

Wcislo, W.T. (1995) Sensilla numbers and antennal morphology of parasitic and non-parasitic bees (Hymenoptera, Apoidea). Int. J. Insect Morphol. Embryol., 24, 63-81.

Wittwer, B., Hefetz, A., Simon, T., Murphy, L.E.K., Elgar, M.A., Pierce, N.E. \& Kocher, S.D. (2017) Solitary bees reduce investment in communication compared with their social relatives. Proc. Natl Acad. Sci. USA, 114, 6569-6574.

Wyatt, T.D. (2014) Pheromones and Animal Behaviour. 2nd Edition. Cambridge University Press, Cambridge, UK.

Yan, X.-Z., Deng, C.-P., Sun, X.-J. \& Hao, C. (2014) Effects of various degrees of antennal ablation on mating and oviposition preferences of the diamondback moth, Plutella xylostella L. J. Integr. Agric., 13, 1311-1319. 
Zacharuk, R.Y. (1985) Antennae and sensilla. In: G.A. Kerkut \& L.I. Bilbert (Eds) Comprehensive Insect Physiology, Biochemistry and Pharmacology, vol. 6, pp. 1-69. Pergamon Press, Oxford, UK.

Zhang, S., Zhang, Z., Kong, X. \& Wang, H. (2013) Sexual dimorphism in antennal morphology and sensilla ultrastructure of Dendrolimus tabulaeformis Tsai et Liu (Lepidoptera: Lasiocampidae). Microsc. Res. Tech., 76, 50-57.

Zhang, S., Zhang, Z., Kong, X., Wang, H., Luo, J. \& Yang, Z. (2015) Sensilla on different organs of female and male Telenomus dendrolimusi Chu (Hymenoptera: Scelionidae). Microsc. Res. Tech., 78, 1010-1018.

Zhang, S., Hou, L., Cheng, B. \& Xi, J. (2017) Morphology and distribution of the antennal sensillia of the leaf beetle, Ambrostoma quadriimpressum (Coleoptera: Chrysomelidae). Trans. Am. Entomol. Soc., 143, 757-772.

Zheng, H., Liu, H., Guo, S., Yi Yan, Y., Zong, S. \& Zhang, J. (2014) Scanning electron microscopy study of the antennal sensilla of Catocala remissa. Bull. Insectol., 67, 63-71.

Zhu, W., Zhou, S., Wang, S., Han, D., Chen, J. \& Fu, Y. (2017) Ultrastructure and distribution of antennal sensilla of the chilli thrips Scirtothrips dorsalis Hood (Thysanoptera: Thripidae). Microsc. Res. Tech., 80, 1283-1296. 